\title{
Sorption of Pb (II) From Aqueous Solution by Nio/Activated Carbon Nanocomposite
}

\author{
Hamedreza Javadian, Montserrat Ruiz, Ana Maria Sastre \\ Universitat Politècnica de Catalunya, Department of Chemical Engineering \\ ETSEIB, Diagonal 647, 08028 Barcelona, Spain \\ hamedreza.javadian@upc.edu; montserrat.ruiz@upc.edu; ana.maria.sastre@upc.edu
}

\section{Extended Abstract}

Due to toxic effects of $\mathrm{Pb}$ (II) on the living organisms, industrial effluents should be treated before discharging into environment for protection of public health and environmental surroundings [1,2]. Amongst all techniques for removal of metals, adsorption has become as one of the most preferable techniques because of its high performances and costeffectiveness [3]. Previous investigations found that the loading of nanoparticles on adsorbents significantly increased the sorption of pollutants [4].

In this study, NiO/Rosa Canina-L seeds activated carbon nanocomposite (NiO/ACNC) was prepared by ultrasoundassisted in situ chemical precipitation technique and $\mathrm{Pb}$ (II) removal was investigated. The nanocomposite was characterized by FE-SEM and N2 adsorption-desorption isotherm. The FE-SEM result showed that the sample had a smooth surface without porous structure before activation. After activation process, it showed a heterogeneous and porous surface that was suitable for loading of nanoparticles. The particles were formed homogeneous and nearly spherical, with the sizes less than $100 \mathrm{~nm}$ in diameter. According to $\mathrm{N} 2$ adsorption-desorption isotherm result, mesoporous structure existed in the adsorbent. The effect of different parameters such as contact time (0-120 min), initial metal ion concentration $(25-200 \mathrm{mg} / \mathrm{L})$, temperature $(298,318$ and $333 \mathrm{~K})$, amount of adsorbent $(0.002-0.007 \mathrm{~g})$ and solution $\mathrm{pH}(1-7)$ on the adsorption process was investigated by batch method. The equilibrium data were well fitted by Langmuir model type 1 (R2>0.99). The maximum adsorption capacity (qm) of NiO/ACNC was $1428.57 \mathrm{mg} / \mathrm{L}$. Thermodynamic parameters $\left(\Delta \mathrm{G}^{\circ}\right.$, $\Delta \mathrm{H}^{\circ}$ and $\Delta \mathrm{S}^{\circ}$ ) were also calculated. The results showed that the adsorption of $\mathrm{Pb}$ (II) onto NiO/ACNC was feasible, spontaneous and exothermic. It was confirmed that $\mathrm{NiO} / \mathrm{ACNC}$ had a great potential for removal of $\mathrm{Pb}$ (II) from aqueous solution.

Keywords: Adsorption; $\mathrm{Pb}$ (II), Nanocomposite, Isotherm, Thermodynamic

\section{References}

[1] F. Geyikci, E. Kilic, S. Coruh, S. Elevli, "Modelling of lead adsorption from industrial sludge leachate on red mud by using RSM and ANN," Chem. Eng. J., vol. 183, pp. 53-59, 2012.

[2] J. Kong, Q. Yue, S. Sun, B. Gao, Y. Kan, Q. Li, Y. Wang, "Adsorption of Pb(II) from aqueous solution using keratin waste - hide waste: Equilibrium, kinetic and thermodynamic modeling studies," Chem. Eng. J., vol. 241, pp. 393-400, 2014.

[3] M. Ghasemi, M. Naushad, N. Ghasemi, Y. Khosravi-fard, "A novel agricultural waste based adsorbent for the removal of $\mathrm{Pb}(\mathrm{II})$ from aqueous solution: Kinetics, equilibrium and thermodynamic studies," J. Ind. Eng. Chem., vol. 20, pp. 454-461, 2014.

[4] M. Ghaedi, M. Nejati Biyareh, S. Nasiri Kokhdan, S. Shamsaldini, R. Sahraei, A. Daneshfar, S. Shahriyar, "Comparison of the efficiency of palladium and silver nanoparticles loaded on activated carbon and zinc oxide nanorods loaded on activated carbon as new adsorbents for removal of Congo red from aqueous solution: Kinetic and isotherm study," Mater. Sci. Eng., vol. 32, pp. 725-734, 2012. 